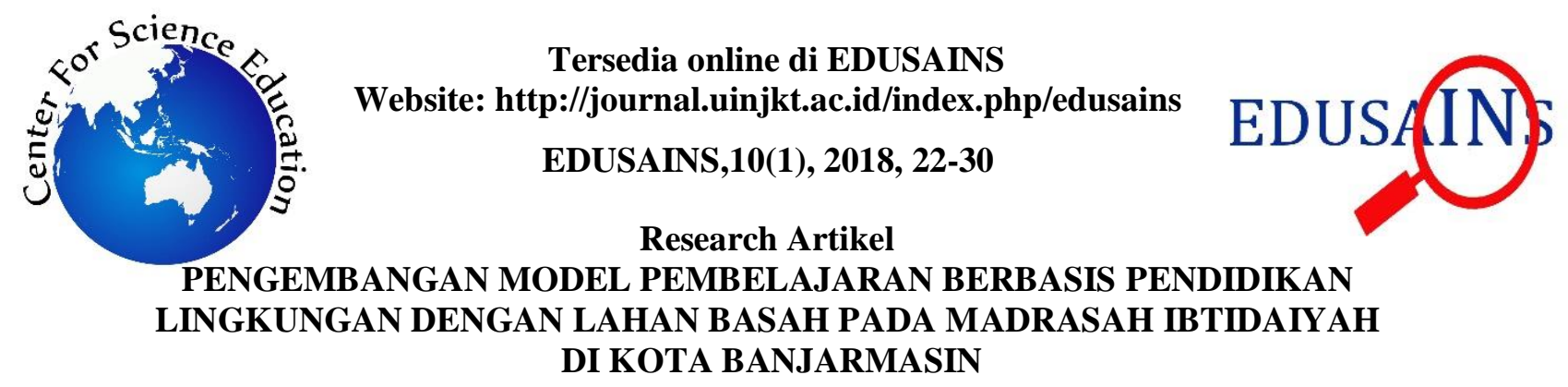

\title{
LEARNING MODEL DEVELOPMENT BASED ON ENVIRONMENTAL EDUCATION USING WETLAND AT ISLAMIC ELEMENTARY SCHOOLS IN BANJARMASIN
}

\author{
Khairunnisa ${ }^{1}$, Salamah ${ }^{1}$ \\ ${ }^{1}$ UIN Antasari, Banjarmasin, Indonesia \\ khairunnisa@uin-antasari.ac.id
}

\begin{abstract}
This research is aimed to know how the environmental based learning by introducing wetland at Islamic elementary schools in Banjarmasin have been going recently (teachers' understanding, design, process, and learning evaluation), and how are the learning model which is based on environmental education on wetland can be developed and implemented at Islamic elementary schools in Banjarmasin. This research is a developmental research with Research and Development $(R \& D)$ approach through preliminary research, small scale testing model development, and wide scale testing model validation. The research is conducted at MI Darun Nasihin, MI Sulamut Taufiq, and MI Nurul Islam.The data is collected through documentation, questionnaires, interview, and observation. The data is analyzed descriptive-qualitatively through data reduction, data display, and verification. After wide scale testing on the model which was developed and tried out using learning instrument adapted with the materials about ecosystem balance, the materials were then taught to the six graders of Islamic elementary school through the following implementation steps: orientation, relating, exploration, finding problems, group investigation, work result discussion, clarification, and resolution. The model is proved to be able to be developed at Islamic elementary schools in Banjarmasin, viewed from the students learning evaluation with the percentage in very good category. Students behavior also shows positive influence which means the learning has been able to stimulate students' positive behaviors such as caring, being open-minded, being appreciative to what people are saying, and being responsible. The model development is also supported by good response from students and teachers towards students' workbook and teaching learning process.
\end{abstract}

Keywords:learning model development; environmental education; wetland

\begin{abstract}
Abstrak
Penelitian ini bertujuan untuk mengetahui bagaimana pembelajaran berbasis lingkungan dengan memperkenalkan lahan basah di sekolah dasar Islam di Banjarmasin telah berjalan baru-baru ini (pemahaman, desain, proses, dan evaluasi pembelajaran guru), dan bagaimana model pembelajaran yang didasarkan pada pendidikan lingkungan di lahan basah dapat dikembangkan dan diimplementasikan di sekolah dasar Islam di Banjarmasin. Penelitian ini merupakan penelitian pengembangan dengan pendekatan Research and Development (R \& D) melalui penelitian pendahuluan, pengembangan model pengujian skala kecil, dan validasi model pengujian skala luas. Penelitian dilakukan di MI Darun Nasihin, MI Sulamut Taufiq, dan MI Nurul Islam. Data dikumpulkan melalui dokumentasi, angket, wawancara, dan observasi. Data dianalisis secara deskriptif-kualitatif melalui reduksi data, tampilan data, dan verifikasi. Setelah pengujian skala luas pada model yang dikembangkan dan diujicobakan menggunakan instrumen pembelajaran yang disesuaikan dengan materi tentang keseimbangan ekosistem, materi kemudian diajarkan kepada enam siswa sekolah dasar Islam melalui langkah-langkah implementasi berikut: orientasi, berhubungan, eksplorasi, penemuan masalah, investigasi kelompok, diskusi hasil kerja, klarifikasi, dan resolusi. Model ini terbukti dapat dikembangkan di sekolah dasar Islam di Banjarmasin, dilihat dari evaluasi pembelajaran siswa dengan persentase dalam kategori sangat baik. Perilaku siswa juga menunjukkan pengaruh positif yang berarti pembelajaran telah mampu merangsang perilaku positif siswa seperti kepedulian, berpikiran terbuka, menghargai apa yang dikatakan orang, dan bertanggung jawab. Pengembangan model juga didukung oleh respon yang baik dari siswa dan guru terhadap buku kerja siswa dan proses pembelajaran.
\end{abstract}

Kata Kunci:pengembangan model pembelajaran; pendidikan lingkungan; lahan basah

Permalink/DOI: http://dx.doi.org/10.15408/es.v10i1.7217

EDUSAINS, p-ISSN 1979-7281 e-ISSN 2443-1281

This is an open access article under CC-BY-SA license (https://creativecommons.org/licenses/by-sa/4.0/) 


\section{PENDAHULUAN}

Manusia dan lingkungan memiliki hubungan yang tidak dapat terpisahkan. Manusia sangat bergantung pada lingkungan yang memberikan sumberdaya alam untuk tetap bertahan hidup. Adanya keterbatasan daya dukung (carrying capacity) lingkungan, menyebabkan manusia harus memperhatikan kelestarian lingkungan agar fungsifungsi lingkungan dapat berjalan sehingga dapat mendukung penghidupan berkelanjutan. Untuk membentuk manusia yang sadar akan pentingnya lingkungan bagi kehidupan maka perlu usaha yang dapat membina, mengarahkan dan menjadikan seseorang mempunyai jiwa mencintai lingkungan hidup.

Lingkungan adalah semua faktor luar, fisik, dan biologis yang secara langsung berpengaruh terhadap ketahanan hidup, pertumbuhan, perkembangan, dan reproduksi organisme, sedangkan yang dimaksud lingkungan hidup adalah kesatuan ruang dengan semua benda, daya, keadaan, dan makhluk hidup, termasuk di dalamnya manusia dan perilakunya, yang mempengaruhi kelangsungan perikehidupan dan kesejahteraan manusia serta makhluk hidup lainnya (Nina Setiyani, 2013).

Lingkungan adalah anugerah dari Allah SWT untuk manusia dan makhluk hidup lainnya. Dalam beberapa ayat Al-Qur'an ditegaskan bahwa semesta alam diciptakan oleh Allah sebagai bukti kasih sayang-Nya kepada manusia. Al-Qur'an banyak berbicara tentang penciptaan alam sebagai fasilitas hidup yang dengannya manusia dapat memanfaatkannya sehingga dapat bersyukur kepada-Nya. Sebagaimana dalam Q.S Al-Hijr: 1920 Allah berfirman yang artinya Allah menegaskan telah menyiapkan fasilitas kehidupan yang seimbang sebagai penopang kehidupan . kebutuhan terhadap flora yang diperlukan manusia telah disediakan Allah secara seimbang sesuai kebutuhan hidup, dimana pertumbuhan dan penuaiannya sesuai dengan kebutuhan dan keperluan makhluk hidup (Sukarni, 2013:35). Menurut UU No 32 Tahun 2009, Lingkungan hidup adalah kesatuan ruang dengan semua benda, daya, keadaan, dan makhluk hidup, termasuk manusia dan perilakunya, yang mempengaruhi alam itu sendiri, kelangsungan perikehidupan, dan kesejahteraan manusia serta makhluk hidup lain.

Sebagian besar penduduk di dunia bermukim dalam lingkungan kawasan lahan basah atau dekat dengan lahan basah. Banyak kota-kota di dunia dibangun pada kawasan lahan basah, salah satunya kota Banjarmasin yang terletak di ambang Sungai Barito. Pentingnya lahan basah mengalami perubahan seiring dengan perjalanan waktu. Lahan basah sekarang ini secara langsung atau tidak langsung, diakui atau tidak, mempunyai peranan yang sangat penting, karena sumberdaya yang tersedia dan fungsinya ada yang dapat diukur dan ada yang tidak dapat diukur. Hal tersebut sesuai dengan apa yang disampaikan Mitsch dan Gosselink dalam Rabiatul Adawiyah (2013) bahwa lahan basah dapat dianggap sebagai ginjalnya bentang lahan (the kidney of the landscape), karena mempunyai peranan penting dalam siklus hidrologi dan siklus biogeokimia, dan sebagai supermarket biologi (biological supermarkets), karena keanekaragaman hayatinya yang tinggi dan dukungannya terhadap jaring makanan.

Menurut Konvensi Ramsar lahan basah (wetlands) dapat diartikan sebagai lahan yang secara alami atau buatan selalu tergenang air, baik secara permanen ataupun musiman, dengan air yang tergenang ataupun mengalir. Air yang menggenangi lahan basah dapat berupa air tawar, payau, atau asin. Lahan basah adalah kawasan yang kaya akan keanekaragaman hayati. Sedangkan yang dimaksud lahan basah di sini dipilih tertentu saja yaitu sungai atau rawa.

Lahan basah merupakan wilayah yang memiliki tingkat keanekaragaman hayati yang tinggi dibandingkan dengan kebanyakan ekosistem. Manusia memperoleh berbagai manfaat dari lahan basah, baik secara ekonomi, ekologi, maupun budaya. Menyadari begitu besarnya peran lahan basah bagi manusia, maka tentu kelestariannya perlu dijaga dan dijauhkan dari kerusakan. Kerusakan atau hilangnya lahan basah, juga akan menghilangkan peran dan fungsi di 
dalamnya, seperti mencegah banjir, mencegah kebakaran (hutan), mencegah intrusi air laut, sumber penyedia air bersih, mencegah pemanasan global, sumber mata pencaharian, dan sarana pendidikan. Semua orang bertanggung jawab untuk melestarikan, mengelola dan memanfaatkan lahan basah dengan bijak. Bilamana peduli pada kehidupan dan generasi penerus, maka wajib peduli pada kelestarian lahan basah yang ada di sekitarnya. Salah satu cara yang diharapkan dapat melestarikan lahan basah adalah melalui pembelajaran (Zaini, 2014). Pembelajaran ini bisa dilakukan melalui pendidikan lingkungan.

Menurut Pratomo dalam Rifki Afandi (2013) pendidikan lingkungan adalah suatu program pendidikan untuk membina peserta didik agar memiliki pengertian, kesadaran, sikap, dan perilaku yang rasional serta bertanggung jawab tentang pengaruh timbal balik antara penduduk dengan lingkungan hidup dalam berbagai aspek kehidupan manusia. Pendidikan lingkungan hidup adalah pendidikan yang bertujuan untuk mengembangkan sekelompok masyarakat agar memiliki pengetahuan, keterampilan, nilai, dan motivasi untuk menyelesaikan masalah lingkungan menuju pembangunan berkelanjutan. pendidikan lingkungan telah diintegrasikan pada kurikulum sekolah, bukan pada satu mata pelajaran, akan tetapi melalui subyek lain (pengetahuan, bahasa, berhitung, dan sebagainya). Hal ini diartikan dengan menuangkan (infusion) materi pendidikan lingkungan ke dalam berbagai mata pelajaran, sehingga pendidikan di sekolah bernuansa lingkungan, yang diharapkan implikasinya berpengaruh positif bagi siswa dalam mengadopsi dimensi laten pendidikan lingkungan (Robert Steel, 2015).

Anas Salahuddin (2013) menyampaikan nilai karakter peduli lingkungan adalah sikap, tindakan yang selalu berupaya mencegah kerusakan pada lingkungan alam di sekitarnya, dan mengembangkan upaya-upaya untuk memperbaiki kerusakan alam yang sudah terjadi.Sekolah menjadi media yang paling efektif dalam membangun kesadaran dan kepedulian lingkungan. Sekolah seharusnya menyusun metode yang efektif karena peduli lingkungan merupakan salah satu karakter penting yang seyogyanya dimiliki secara luas oleh setiap orang, khususnya para siswa yang menempuh jenjang pendidikan. Membangun karakter peduli lingkungan salah satunya dengan pembiasaan. Menurut Rahmat Mulyana (2009) pembiasaan yang dapat dilakukan adalah: memasukkan konsep karakter peduli lingkungan pada setiap kegiatan pembelajaran, Membuat slogan yang mampu menumbuhkan kebiasaan baik dalam mengelola lingkungan hidup dalam segala tingkah laku masyarakat sekolah, dan Pemantauan secara kontinyu merupakan wujud dari pelaksanaan pembangunan karakter.

Di kota Banjarmasin, banyak sekolahsekolah MI yang letaknya cukup strategis dengan wilayah atau kawasan lingkungan alam yang menjadi ciri khas geografis kota Banjarmasin yaitu kawasan lahan basahnya seperti sungai atau ragam lahan basah lainnya. Karena itu perlu dikembangkan sebuah model pembelajaran untuk pendidikan lingkungan hidup yang berbasis terhadap karakter khas lingkungan lokal setempat. secara ekologi adalah lahan basah.

\section{METODE}

Jenis penelitian ini adalah penelitian pengembangan. Pendekatan yang digunakan dalam pengembangan model ini adalah Research and Development $(R \& D)$.sebagaimana dikemukakan oleh Borg \& Gall (1989) dalam Salamah (2014:54) bahwa Research and Development adalah: " $a$ process used to develop and validate educational products", yaitu suatu proses untuk mengembangkan suatu produk baru atau menyempurnakan yang telah ada agar lebih efektif.Teknik pengumpulan data yang digunakan adalah dokumen, angket, wawancara, observasi, dan tes. Adapun rincian teknik dan tujuan pengumpulan data disesuaikan dengan tahapan pengembangan model, yaitu: studi pendahuluan, pengembangan model uji terbatas, dan validasi model/uji luas (Sugiyono, 2013).

Analisis menggunakan teknik deskriptif kualitatif dan deskriptif kuantitatif. Teknis analisis deskriptif kualitatif digunakan dalam kegiatan studi pendahuluan, sampai saat pengembangan model pembelajaran berbasis pendidikan lingkungan dengan lahan basah pada mata pelajaran IPA di MI yang dapat meningkatkan hasil belajar siswa. 
Sedangkan teknik analisis deskriptif kuantitatif digunakan pada uji validasi model guna menganalisis tingkat perbedaan hasil belajar siswa baik sebelum dilakukan implementasi produk model pembelajaran maupun setelah melaksanakan implementasi produk model pembelajaran berbasis pendidikan lingkungan dengan lahan basah. Analisis data dalam penelitian kualitatif dilakukan saat pengumpulan data berlangsung, dan setelah selesai pengumpulan data dalam periode tertentu. Menurut Arief Furchan (2005:415) Adapun tahapan analisis data dalam penelitian ini adalah: reduksi data, (data reduction), penyajian data (data display), dan verifikasi (conclusion drawing).

Subjek dalam penelitian ini adalah semua bagian yang menjadi pihak/unsur civitas di sekolah MI adalah kepala sekolah, guru-guru dari kelas I sampai dengan VI yang mengajar IPA ataupun mata pelajaran yang terintegrasi dengan IPA, siswa, Tata Usaha (TU) serta pihak-pihak lain yang terlibat dengan implementasi pendididkan lingkungan hidup yang ada di sekolah yang diteliti. Waktu penelitian dilaksanakan pada bulan Juli sampai dengan Oktober atau pada Semester ganjil tahun ajaran 2016/2017. Tempat penelitian dipilih secara purposive atau bertujuan berdasarkan letak dan kedekatan lokasi dengan lingkungan alam yangrepresentatif sebagai lahan basah seperti sungai yang merupakan anak sungai dalam perkotaan (aliran sungai) dan rawa di Kota Banjarmasin yaitu MI Darunnasihin, MI Nurul Islam, dan MI Sulamut taufiq.

\section{HASIL DAN PEMBAHASAN}

\section{Studi Pendahuluan}

Pada studi pendahuluan di beberapa MI yang ada di Banjarmasin, dilihat seperti aspek desain pembelajaran IPA (khususnya materi tentang ekosistem atau lingkungan) yang berjalan selama ini, proses kegiatan belajar mengajar, kondisi guru IPA, kondisi siswa, sarana dan prasarana pembelajaran, serta sikap kepala sekolah dan guru lainnya. Hasilnya terkait pembelajaran dengan pendekatan lingkungan dan menggunakan lahan basah yaitu sungai hampir tidak pernah dilakukan. Guru cenderung melakukan pembelajaran hanya di dalam kelas saja, sangat jarang pembelajaran di luar kelas. Padahal sungai dan rawa adalah halaman sekolah yang juga menjadi tempat bermain anak. Sedangkan dari evaluasi pembelajaran lebih bertumpu pada penguasaan konsep saja, tidak melakukan penilaian pada proses.

\section{Desain Model Pembelajaran}

Desain pembelajaran yang dikembangkan setelah melalui tahapan implementasi pengembangan model (uji terbatas) hingga validasi model (uji luas), maka didapatkan desain model di bawah ini:

Tujuan: menyesuaikan dengan SK/KD pada KTSP 2006 mata pelajaran IPA semester I. Perangkat pembelajaran yang digunakan berupa: Silabus, RPP, LKS, lembar penilaian, materi/bahan ajar, dan media, semua mengacu pada SK/KD pada KTSP 2006 dengan melakukan modifikasi model menggunakan pendekatan lingkungan, CTL, dan inquiry berbasis pendidikan lingkungan dengan lahan basah yang berorientasi terbentuknya karakter peduli dan cinta lingkungan. Dipilihnya CTL karena CTL menyampaikan pesan yang menekankan pada: (1) menghubungkan pengetahuan dan keterampilan, (2) mempelajari konsep-konsep abstrak dengan melakukan aktivitas-aktivitas praktis, dan (3) menghubungkan pelajaran sekolah dengan dunia nyata (Trianto, 2007:26). Sedangkan inquiry menurut Hanry dalam Heppner (2006) inquiry telah menjadi pilihan metode mengajar pengetahuan praktik terbaik untuk memberi kesempatan kepada siswa dengan tujuan mengembangkan keterampilan berfikir yang lebih optimal sementara secara bersamaan merencanakan kerja ilmiah.

Selanjutnya langkah implementasi model secara umum terbagi atas beberapa langkah pembelajaran: (1)Presentasi materi pelajaran bertema keseimbangan lingkungan: membuka, menjelaskan, dan mengembangkan materi pelajaran; (2) Pengamatan lapangan: pengamatan kondisi lingkungan sungai/aliran sungai yang ada di sekitar sekolah (pengamatan kondisi fisik sungai dan aktivitas manusia di sekitar sungai yang dapat mempengaruhi keseimbangan ekosistemnya); (3)Diskusi hasil pengamatan lapangan; (4) Praktikum atau uji coba membuktikan pengaruh limbah hasil aktivitas manusia (detergen: limbah rumah tangga) terhadap kehidupan biota yang ada 
di sungai (praktik menggunakan ikan kecil); (5)Diskusi hasil kerja/praktik dan presentasi: mengembangkan sikap ketelitian, kejujuran, peduli, komunikasi, toleransi, terbuka, dan menghargai pendapat teman, serta tanggung jawab; (6) Mengklarifikasi dan merangkum hasil pembelajaran: dilakukan oleh guru dan siswa secara bersama-sama; (7) Pembuatan produk poster bertema peduli dan cinta lingkungan sebagai bentuk komitmen akhir terbentuknya sikap untuk menjaga dan mencintai lingkungan khususnya lingkungan lahan basah.

Tahapan akhir evaluasi, dilakukan pada tiga ranah yaitu kognitif, afektif dan psikomotorik. Evaluasi hasil belajar kognitif; tes lisan dan tulisan. Evaluasi sikap/proses berupa perilaku berkarakter siswa (ketelitian dan keseriusan dalam memehami dan menguasai materi, kejujuran dalam pengamatan dan mengolah data, peduli teman dalam bekerja, komunikasi, toleransi, terbuka dan menghargai pendapat teman saat berdiskusi dan presentasi, bertanggung jawab). Dan evaluasi psikomotorik/keterampilan meliputi keterampilan dalam melaksanakan praktik/percobaan dan membuat poster cinta lingkungan.

\section{Implementasi atau Pengujian Model}

Pengujian model dilakukan pada MI dengan memperhatikan letak dan kedekatan lokasi dengan lingkungan alam yangrepresentatif sebagai lahan basah seperti sungai yang merupakan anak sungai dalam perkotaan (aliran sungai) dan rawa di Kota Banjarmasin. Untuk pengembangan model (pengujian terbatas) dilakukan pada satu MI yaitu yaitu MI Darunnasihin, sedangkan untuk validasi model (uji luas) dilakukan pada dua MI yaitu MI Nurul Islam dan MI Sulamut Taufiq.

Evaluasi uji terbatas; evaluasi dilakukan terhadap hasil desain model, proses implementasi, dan hasil belajar. Pada uji ini lokasi MI berada di dekat anak sungai yang biasa dipakai warga sekitar untuk melakukan aktivitas MCK. Hasil yang didapatkan adalah respon baik guru maupun siswa sangat baik karena model ini memberikan pengalaman pembelajaran baru dengan pengamatan dan praktik langsung di sungai. Siswa tampak sangat antusias dalam praktik di sungai. Meskipun antusias, kinerja siswa dan perilaku berkarakter dalam proses masih terkategori cukup karena belum terbiasa belajar di luar kelas. Kinerja guru juga belum maksimal karena tidak terbiasa melakukan pengontrolan kelas untuk pembelajaran di lapangan. Selanjutnya pada evaluasi hail belajar siswa sudah terkategori baik.

Setelah dilakukan perbaikan atas evaluasi pada uji terbatas, selanjutnya dilakukan uji luas. Evaluasi juga dilakukan terhadap hasil desain model, proses implementasi, dan hasil belajar. Pada uji luas pertama lokasi MI berada di sekitar anak sungai di pinggir kota yang dipakai sekitar warga untuk berjualan/usaha. Sedangkan pada uji luas kedua lokasi sungai cukup kecil dan masuk perumahan sempit yang juga sering dipakai untuk MCK. Hasil yang didapatkan adalah guru belum maksimal dalam melaksanakan pembelajaran di luar kelas, namun pengkaitan materi dengan kehidupan nyata (relating) sudah tampak alami dan jelas. Guru juga sudah cukup mampu merancang perencanaan pembelajaran dengan langkah model ini. Terkait dengan aktivitas siswa, perilaku berkarakter dan hasil evaluasi pembelajarannya di luar kelas dan percobaan yang dilakukan telah memberikan pengalaman nyata bagi siswa sehingga mereka sangat antusias. Selanjutnya dengan adanya pembuatan poster dan penyampaian komitmen (resolution) memberikan implikasi pembentukan sikap dan peduli lingkungan pada siswa.

Berdasarkan evaluasi dan perbaikan hasil implementasi keterlaksanaan model hingga validasi, dari desain langkah atau tahapan pembelajarannya maka didapatkan:(1)Orientasi: membuka, menjelaskan, menginformasikan tujuan, dan mengembangkan materi pelajaran; (2) Relating: menghubungkan permasalahan di buku dengan kondisi lingkungan sekitar sekolah berupa lahan basah/sungai; (3) Eksplorasi dan menemukan masalah: Pengamatan lapangan ke sungai langsung untuk melihat kondisi lingkungan sungai/aliran sungai yang ada di sekitar sekolah (pengamatan kondisi fisik sungai dan aktivitas manusia di sekitar sungai yang dapat mempengaruhi keseimbangan ekosistemnya); (4) Penyelidikan kelompok: Praktikum atau uji coba membuktikan pengaruh limbah hasil aktivitas manusia (detergen: limbah rumah tangga) terhadap kehidupan biota yang ada di sungai (praktik menggunakan ikan kecil); 
Diskusi hasil kerja/praktik dan presentasi; (6) Klarifikasi pembelajaran; (7) Resolusi: Pembuatan produk poster bertema peduli dan cinta lingkungan sebagai bentuk komitmen akhir terbentuknya sikap untuk menjaga dan mencintai lingkungan khususnya lingkungan lahan basah. Perbaikan langkah atau tahapan ini menentukan pula perubahan dari perencanaan pembelajarannya (RPP). Sedangkan dari perangkat perencanaan pembelajaran lainnya tidak banyak perubahan.

\section{Validasi Model}

Pengujian model dilakukan dengan menggunakan metode eksperimen semu (quasi eksperiment) dengan pemilihan kelas eksperimen dan kelas kontrol. Uji ini dilakukan sebanyak tiga kali. Hasilnya dapat dilihat pada Tabel 1 .

Tabel 1. Data Hasil Validasi Model Pembelajaran Berbasis Pendidikan Lingkungan Lahan Basah

\begin{tabular}{lllclc}
\hline Kegiatan & $\begin{array}{l}\text { Rata- } \\
\text { rata }\end{array}$ & Sd & $\begin{array}{l}\text { Nilai t } \\
\text { hitung }\end{array}$ & df & t-tabel \\
\hline Kel. Eks 1 & 72,73 & 2,66 & 16,55 & 208 & 1,98 \\
Kel. Kon1 & 66,01 & 3,94 & & & \\
\hline Kel. Eks 2 & 73,55 & 2,55 & 20,47 & 208 & 1,98 \\
Kel. Kon2 & 67,32 & 3,01 & & \multirow{2}{*}{208} & \multirow{2}{*}{1,98} \\
\hline Kel. Eks 3 & 74,71 & 2,50 & 23,56 & & \\
Kel. Kon3 & 68,59 & 2,32 & & & \\
\hline
\end{tabular}

Sumber: Laporan Hasil Penelitian

Berdasarkan Tabel 1. menunjukkan nilai rata-rata kelompok eksperimen lebih tinggi daripada kelas kontrol pada ketiga validasi. Harga t hitung juga lebih tinggi dari t-tabel, sehingga disimpulkan model pembelajaran berbasis pendidikan lingkungan dengan lahan basah efektif meningkatkan hasil belajar siswa.

\section{Data Keterangan Model}

Pelaksanaan model ini memberikan implikasi keterterapan pada beberapa aspek yang diobservasi misalnya kinerja guru, aktivitas dan kinerja siswa, serta perilaku berkarakter siswa. Hasilnya tampak pada Tabel 2, Tabel 3, dan Tabel 4.

Tabel 2. Data Hasil Observasi Kinerja Guru dalam Implementasi Model

\begin{tabular}{lccc}
\hline \multicolumn{1}{c}{ Aspek yang diamati } & \multicolumn{3}{c}{ Rata-rata nilai } \\
\cline { 2 - 4 } & MI 1 & MI 2 & MI 3 \\
\hline $\begin{array}{l}\text { Pelaksanaan tahapan } \\
\text { pembelajaran keseluruhan, }\end{array}$ & 3,05 & 2,34 & \\
$\begin{array}{l}\text { pengelolaan waktu, } \\
\text { dorongan untuk membentuk } \\
\text { perilaku berkarakter dan }\end{array}$ & $\begin{array}{c}\text { Cukup } \\
\text { baik }\end{array}$ & $\begin{array}{c}\text { Kurang } \\
\text { baik }\end{array}$ & Baik \\
\hline
\end{tabular}

keterampilan sosial

khususnya terkait sikap

peduli dan cinta lingkungan,

dan pensuasanaan kelas

Sumber: Laporan Hasil Penelitian

Berdasarkan Tabel 2. di atas bahwa kinerja guru mengalami dinamika antara satu MI dengan yang lain. Secara umum kinerja guru paling tinggi MI terakhir saat uji luas, hal ini karena pada uji luas sudah dipersiapkan secara matang guru mitra untuk mengimplementasikan model. Guru pun sudah mampu merancang perencanaan pembelajaran serupa dengan model ini. Pada MI 2 hasil kurang baik dikarenakan dorongan kepada siswa untuk memiliki keterampilan sosial khususnya sikap peduli lingkungan belum tercapai. Ini disebabkan waktu yang tidak tersedia untuk membuat poster secara baik dan kesempatan mempresentasikannya.

Selanjutnya saat implementasi model selain kinerja guru juga dilakukan observasi keterterapan model terhadap aktivitas dan kinerja siswa sebagaimana Tabel 3 .

Tabel 3. Data Hasil Observasi aktivitas dan Kinerja Siswa dalam Implementasi Model

\begin{tabular}{|c|c|c|c|}
\hline \multirow[t]{2}{*}{ Aspek yang diamati } & \multicolumn{3}{|c|}{ Rata-rata nilai } \\
\hline & MI 1 & MI 2 & MI 3 \\
\hline $\begin{array}{l}\text { Aktivitas kelompok selama } \\
\text { pembelajaran, kegiatan } \\
\text { proyek dan praktik, kinerja } \\
\text { lisan, dan kinerja produk }\end{array}$ & $\begin{array}{c}3,56 \\
\text { Cukup } \\
\text { baik }\end{array}$ & $\begin{array}{c}3,71 \\
\text { Cukup } \\
\text { baik }\end{array}$ & $\begin{array}{l}4,21 \\
\text { Baik }\end{array}$ \\
\hline
\end{tabular}

Sumber: Laporan Hasil Penelitian

Observasi juga dilakukan terhadap kinerja siswa. Berdasarkan Tabel di atas tampak bahwa kinerja MI 1 dan MI 2 hanya terkategori cukup baik. Hal ini disebabkan pada aktivitas kelompok dan kegiatan proyek belum maksimal. Siswa belum terbiasa melakukan kegiatan praktik di sungai dan membuat poster cinta lingkungan. Namun kondisi ini teratasi pada tahapan akhir uji luas, dimana kategori kinerja siswa sudah baik.

Selama implementasi model juga dilakukan observasi terhadap perilaku berkarakter siswa, yang akan ditampilkan pada Tabel 4.

Tabel 4. Data Observasi Perilaku Berkarakter Siswa selama Implementasi Model

\begin{tabular}{cccc}
\hline Perilaku berkarakter & \multicolumn{3}{c}{ Rata-rata persentase (\%) } \\
\cline { 2 - 4 } siswa & MI 1 & MI 2 & MI 3 \\
\hline Ketelitian & 25 & 25 & 34 \\
Kejujuran & 29 & 25 & 34 \\
Peduli lingkungan & 34 & 25 & 33
\end{tabular}

EDUSAINS. Volume 10 Nomor 01 Tahun 2018, 27-30 This is an open access article under CC-BY-SA license (https://creativecommons.org/licenses/by-sa/4.0/) 


\begin{tabular}{cccc}
\hline Perilaku berkarakter & \multicolumn{3}{c}{ Rata-rata persentase (\%) } \\
\cline { 2 - 4 } siswa & MI 1 & MI 2 & MI 3 \\
\hline Komunikasi & 25 & 27 & 34 \\
Toleransi & 20 & 25 & 34 \\
Terbuka dan & 25 & 34 & 34 \\
menghargai pendapat & 35 & 34 & 34 \\
Bertanggung jawab & 35
\end{tabular}

Sumber: Laporan Hasil Penelitian

Data observasi perilaku berkarakter siswa sebagaimana Tabel 4. di atas menunjukkan umumnya masih perlu banyak ditingkatkan lagi karena rata-rata nilai paling banyak hanya $34 \%$. Namun dari perilaku peduli lingkungan dan bertanggung jawab cukup tinggi dari ketiga MI karena keterterapan model memiliki tahapan yang mendorong siswa memahami fakta lingkungan dan dorongan untuk peduli dan menjaganya.

\section{Pembahasan}

Berdasarkan sajian data yang sudah ada, selanjutnya diberikan pembahasan yang difokuskan pada model pembelajaran berbasis pendidikan lingkungan dengan lahan basah yang dapat dikembangkan di MI Kota Banjarmasin meliputi desain, implementasi dan hasil pengembangannya. Dalam pelaksanaanya model ini telah memberikan pengalaman pembelajaran baru bagi guru dan siswa. Banyaknya MI di Banjarmasin yang berlokasi dekat dengan sungai ataupun aliran sungai perkotaan, idelanya bisa menjadi sumber belajar optimal terkait materi lingkungan dan diharapkan dapat membentuk karakter yang peduli lingkungan.

Implementasi model yang dilakukan melalui uji terbatas dan uji luas pada MI yang berlokasi dekat dengan sungai atau aliran sungai ini telah mengalami beberapa perbaikan berdasarkan masukkan dari ahli dan guru mitra yang melaksanakan model. Dari tahapan atau langkah pembelajaran yang didapatkan setelah akhir uji validasi, secara proses catatan dalam pelaksanaan pembelajaran dengan model ini memiliki beberapa persiapan yang perlu dilakukan guru seperti media untuk praktikum dan pembuatan poster. Guru juga harus memperhatikan aspek pengelolaan waktu dan pengontrolan kegiatan siswa dikarenakan kegiatan sebagian besar dilakukan di luar kelas. Hal lain yang juga perlu diperhatikan dalam tahapan ini adalah pentingnya tahapan praktikum untuk membuktikan adanya hubungan kegiatan manusia dengan kehidupan biota di sungai. Kegiatan ini merupakan bagian penting inkuiri karena siswa mendapatkan pengetahuan melalui pengalaman langsung dan pembuktian sendiri (Kt dan Elly Wijayanti, 2013). Tahapan lain yang juga perlu penekanan adalah mempresentasikan poster cinta lingkungan yang telah dibuat siswa sebagai bentuk komitmen kepedulian dan cinta lingkungan.

Berdasarkan data evaluasi hasil belajar melalui eksperimen telah didapatkan hasil bahwa implementasi model ini dalam uji validasi menunjukkan berpengaruh terhadap peningkatan hasil belajar. Hal ini mendukung karena tahapan proses yang dilaksanakan telah membuat siswa memahami secara kontekstual materi yang diajarkan sehingga berpengaruh terhadap hasil kognitif. Selain itu berdasarkan hasil observasi Siswa juga mengalami perkembangan kinerja dan perilaku berkarakter yang baik. Karakter yang terasah baik adalah peduli, terbuka dan menghargai pendapat teman serta bertanggung jawab. Hal ini karena siswa terkondisikan untuk banyak berinteraksi untuk saling bekerjasama menemukan konsep yang dikendaki pembelajaran. Ini sesuai dengan yang disampaikan Bellen dalam Endang Komara (2014) bahwa belajar yang interaktif akan mendorong berkembangnya keterampilan berfikir, keterampilan sosial dan keterampilan praktis. Selanjutnya perilaku berkarakter peduli dan cinta lingkungan yang terasah dalam resolution dengan membuat poster dianggap sebagai bagian dari domain ke IV dari lima ranah pelajaran sains yaitu feeling and valuing (attitudinal domain). Domain ini merupakan bagian dari wujud nurturent effect (dampak penggiring) yang diyakini lahir dan berkembang dari scientific attitude, sikap ilmiah. Yaitu nilai-nilai ilmiah dan moral dalam usaha untuk membaca alam untuk emnjawab hubungan sebab akibat dari gejala dan permasalahan alam (Damiyati, 2013).

\section{PENUTUP}

Berdasarkan hasil penelitian yang telah dipaparkan, maka dapat diberikan simpulan: (1) studi pendahuluan menunjukkan bahwa pembelajaran IPA materi terkait lingkungan 
umumnya hanya dilaksanakan di kelas tanpa mengaitkan dengan kondisi kontekstual lingkungan sekitar seperti sungai yang merupakan lahan basah dominan di Kota Banjarmasin, (2) implementasi model pembelajaran berbasis pendidikan lingkungan ini didesain dengan didukung model CTL dan pendektan lingkungan, dengan tahapan yaitu; orientasi, relating, eksplorasi, penyelidikan kelompok, diskusi hasil, klarifikasi, dan resolusi, (3) hasil pengembangan model pembelajaran berbasis pendidikan lingkungan dengan lahan basah ini dibuktikan dapat dikembangkan pada MI di Kota Banjarmasin karena berdasarkan hasil evaluasi belajar berpengaruh dapat meningkatkan, serta berpengaruh positif/baik terhadap perilaku berkarakter siswa seperti peduli dan cinta lingkungan, menghargai pendapat teman serta bertanggung jawab.

\section{UCAPAN TERIMAKASIH}

Terima kasih sebesar-besarnya penulis sampaikan kepada Puslit UIN Antasari Banjarmasin serta semua pihak yang telah memberikan dukungan sehingga pelaksanaan penelitian kelompok ini bisa selesai dan dipertanggungjawabkan dengan baik.

\section{DAFTAR PUSTAKA}

Al-Qur'an Terjemah. 2013. Jakarta: Lautan Lestari

Adawiyah, R. 2014. Pengembangan Kearifan Sikap dan Perilaku melalui Pendidikan Lingkungan Berbasis Lahan Basah. Lentera Jurnal Ilmiah Kependidikan, 8(2), 63-75.

Afandi, R. 2013. Integrasi Pendidikan Lingkungan Hidup melalui Pembelajaran IPS di Sekolah dasar sebagai Alternatif Menciptakan Sekolah Hijau. Jurnal Pedagogia, 2(1).

Djumhana, N. 2009. Pembelajaran Ilmu Pengetahuan Alam. Jakarta: Dirjen Pendidikan Islam Departemen Agama.

Furchan, A. 2005. Pengantar Penelitian dalam Pendidikan. Surabaya: Usaha Nasional

Heppner. 2006. Inquiry: Does it Favor the Prepared Mind?The American Biology Teacher, 68(7), 390-394.
Ilmiyah, N. 2011. Pengembahan Bahan Ajar Materi Pencemaran Lingkungan dengan Strategi Penyelidikan Kelompok pada SMA 3 Amuntai. Unpublished Master thesis, Program studi Magister Pendidikan Biologi Pascasarjana Unlam. Banjarmasin.

Komara, E. 2014. Belajar dan Pembelajaran Interaktif. Bandung: PT. Refika Aditama.

Mulyana, R. 2009. Penanaman Etika Lingkungan melalui Sekolah Peduli dan Berbudaya Lingkungan. Tubula rasa, 6(2).

Robert, S, dkk. 2015. Review Implementasi Pendidikan Lingkungan di Provinsi jambi., Biologi, Sains, Lingkungan, dan Pembelajarannya. Seminar Nasional XII, Prodi Pendidikan Biologi FKIP Universitas Sebelas Maret, Surakarta.

Salahuddin, A.,Alkrienchiechie, I. 2013. Pendidikan Karakter, Pendidikan Berbasis Agama dan Budaya Bangsa. Bandung: Pustaka Setia.

Salamah. 2014. Pengembangan Model Kurikulum Holistik Pendidikan Agama Islam pada Madrasah Tsanawiyah. Yogyakarta: Aswaja.

Sanjaya, W. 2008. Perencanaan dan Desain Sistem Pembelajaran. Jakarta: Kencana Prenada Media.

Sukarni. 2011. Fikih Lingkungan Hidup Perspektif Ulama Kalimantan Selatan. Jakarta: Kementerian Agama RI.

Sugiyono. 2013. Metode penelitian Pendidikan. Bandung: Alfabeta.

Trianto. 2007. Model-Model Pembelajaran Inovatif Berorientasi Konstruktivis. Surabaya: Prestasi Pustaka.

Wijayanti, E., Syahruddin,. Nanci, R. 2013. Pengaruh Pembelajaran Inkuiri Berbantuan Lingkungan sebagai Sumber Belajar terhadap Pemahaman Konsep IPA Siswa SD Kelas V di Gugus IVX Buleleng. E-Jurnal Universitas Pendidikan Ganesha, 32(1), 189-190. 
Zaini, M. 2010. Peluang dan Tantangan menggunakan Lahan Basah dalam Mengajarkan Konsep Ekologi dan Kesadaran Lingkungan. Pentingnya Bersahabat dengan Alam untuk Mengembalikan Kenaekaragaman Hayati Lingkungan Lahan Basah di Kalimantan. Gebyar sains, Prodi Pendidikan Biologi FKIP Universitas Lambung Mangkurat, Banjarmasin.
Zuchdi, D., Prasetya, K.Z., Siasah, M. 2013). Model Pendidikan Karakter. Yogyakarta: MP. 